\title{
Development of High Quality No Fine Concrete
}

\author{
by \\ Dr. G. Nandini Devi \\ Professor, Department of Civil Engineering, \\ Adhiyamaan College of Engineering, Hosur, Tamilnadu, India. \\ Email: gdevi80@gmail.com \\ Development of High Quality No Fine Concrete
}

\begin{abstract}
:
Natural sand is being extorted at an increasing rate. Construction industry is looking for an alternative material for sand and research is going on to find new innovative concrete. No fines concrete has been generally used for paving applications, other non-structural application, such as reinforced panels, acoustic, thermal and permeability properties because of its previous nature. In this work, $12.5 \mathrm{~mm}$ size coarse aggregate is used in place of usually used $20 \mathrm{~mm}$ size in no fine concrete with various mix ratio of cement and $12.5 \mathrm{~mm}$ coarse aggregate. Specimens were casted and tested for its mechanical properties. Results are compared with M25 conventional concrete.
\end{abstract}

Keywords: Natural sand, No Fine Concrete, Tensile strength, Flexural strength, Innovative concrete, Compressive strength.

\section{NTRODUCTION}

Concrete is the base of all construction activity worldwide and is the second most used material after water, with nearly 3 tonnes used yearly by each person on earth. India uses about 450 million cubic metre of concrete per annum. Natural sand is being extorted at an increasing rate. As a result, prices are being pushed up because of the increasing scarcity of natural sand. In most areas of India, the mining of natural sand has been banned. So construction industry is looking for an alternative material for sand and research is going on to find new innovative concrete without its basic ingredients like cement, sand and coarse aggregate, thus leading to fly ash concrete, geoploymer concrete, recycled waste aggregate etc.

No-fines concrete is generally a crushed rock or gravel of $20 \mathrm{~mm}$ single size aggregate coated in a cement slurry with no fine aggregate addition. Very often only single sized coarse aggregate, of size passing through $20 \mathrm{~mm}$ retained on $10 \mathrm{~mm}$ is used. It has good drainage properties due to its open texture. The ratio of aggregate to cement by volume is generally $6: 1$ or $10: 1$ by mass. Because it does not contain any fine aggregate the mix cannot segregate and consequently it can be dropped from a height. Formwork pressures are lower than for normal concrete so shutters can be lighter and pour height lifts greater.

The strength of no-fines concrete is dependent on the water/cement ratio, aggregate-cement ratio and unit weight of concrete. The water/cement ratio for satisfactory consistency will vary between a narrow range of 0.38 and 0.52 . The bond strength of no-fines concrete is very low and, therefore, reinforcement is not used in conjunction with no-fines concrete. However, if reinforcement is required to be used in no-fines concrete, it is advisable to smear the reinforcement with cement paste to improve the bond and also to protect it from rusting.

For quality control and quality assurance, unit weight or bulk density is the preferred measurement because some fresh concrete properties, such as slump, are not meaningful for pervious concrete.

SiddharthTalsania et al have analysed the strength and permeability of pervious concrete by replacing cement with various industrial waste materials such as waste glass powder, hypo sludge, ceramic waste and rice husk ash.

\section{MATERIALS AND METHODS}

\subsection{Materials Used and Mix Proportioning}

Materials used are cement, coarse aggregate and water. For conventional concrete mix of M25 Grade, proportion as recommended by IS 456:2000 is used i.e. 1:1:2 with water-cement ratio of 0.45 . Coromandal king OPC 53 Grade cement, fine aggregate conforming to Zone III, $20 \mathrm{~mm}$ size coarse aggregate are used. For No Fine Concrete, Coromandal king OPC 53 Grade cement, coarse aggregate of size passing through $20 \mathrm{~mm}$ retained on $10 \mathrm{~mm}$ are used. Potable tap water

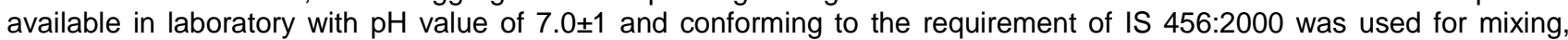
casting the concrete and curing the specimen as well. Cubes, cylinders and prisms were casted, cured using water and tested. Table. 1 gives the mix proportion of conventional and No Fine Concrete. Figure.1 and Figure. 2 shows the mixing and casting of specimens.

\subsection{Testing Of Specimen}

The following tests were carried out as per IS: 3495 (Part 1):1992 to find the compressive strength, split tensile strength and flexural strength of specimens. 


\section{a). Compressive Strength Test}

Compressive strength test on cube specimen of size $150 \mathrm{~mm}$ was conducted at 7 th, 14 th and 28th days. CTM (compression testing machine) of capacity 100 tonnes is used. The concrete specimen were placed with flat faces. The compressive strength test was carried out by applying a uniform rate of loading to the concrete specimen by compressive testing machine. The load was applied till failure occurred on the concrete specimen. The maximum load at which the specimen failed was noted. Figure. 3 shows testing of cube specimens.

\section{b). Split Tensile Strength Test}

Split tensile strength test on cylinder specimen of size $150 \mathrm{~mm}$ diameter and $300 \mathrm{~mm}$ height was conducted at $28 \mathrm{th}$ day to measure tensile strength of concrete. Figure. 4 shows testing of cylinder specimen for split tensile strength.

\section{c). Flexural Strength Test}

Flexural strength was conducted on prism of size $100 \mathrm{mmX} 100 \mathrm{~mm} \times 500 \mathrm{~mm}$ at 28 th day to measure the flexure strength of concrete. Factors influencing the flexural strength are degree of compaction, porosity, and the aggregate-to-cement $(\mathrm{A} / \mathrm{C})$ ratio. Figure. 5 shows the flexural test on prism specimen.

\section{RESULTS AND DISCUSSIONS}

The cube compressive strength of conventional concrete at 28 th day is $37 \mathrm{~N} / \mathrm{mm}^{2}$. For mix M1, M2 and M3, the cube compressive strength at 28th day is $31.5 \mathrm{~N} / \mathrm{mm}^{2}, 27 \mathrm{~N} / \mathrm{mm}^{2}$ and $14 \mathrm{~N} / \mathrm{mm}^{2}$ respectively. Table. 2 shows the results of compression test carried out on cube specimens. In all mixes, it is found that about $50 \%$ of 28 th day strength is reached and about $75 \%$ of 28 th day strength is reached. Table. 3 gives comparison of compressive strength of different mixes. It is found that mixes $\mathrm{M} 1$ and $\mathrm{M} 2$ has reached the design strength i.e. $25 \mathrm{~N} / \mathrm{mm}^{2}$. Figure. 6 shows the comparison of conventional concrete with No fine concrete of different mix ratios.

Split tensile strength of cylinder specimens at 28th day are tabulated in Table. 4 and Figure. 7 shows the split tensile strength of conventional concrete with different mix ratios of No fine concrete. It is observed that no fine concrete has less strength than conventional concrete.

Table. 5 gives flexural test values of No fines concrete at 28 Days curing and Figure. 8 shows the flexural strength of conventional concrete with No fine concrete of different mix ratios. IS 456:2000 recommends the value of $0.7^{\star} \sqrt{\mathrm{fck}}$ for flexural strength. As observed earlier, here also reduction in strength and is tabulated in Table.5

\section{CONCLUSIONS}

From experimental investigation, the following conclusions were made:

$>$ Mixes 1:2 and 1:3 of no fine concrete has reached the design strength i.e. $25 \mathrm{~N} / \mathrm{mm} 2$. Mix 1:2 is $16.7 \%$ more than $\operatorname{mix} 1: 3$.

$>$ Split tensile strength of mix $1: 2$ and $1: 3$ obtained at 28 day is $14 \%$ and $36 \%$ lesser than the conventional concrete.

$>$ Flexural strength of mix $1: 2$ and $1: 3$ obtained at 28 day is $23 \%$ and $57 \%$ lesser than the conventional concrete.

$>$ Grading of $12.5 \mathrm{~mm}$ size coarse aggregate is better than normal $20 \mathrm{~mm}$ size coarse aggregate in No fine concrete. Mix $1: 2$ is found to have mechanical properties close with conventional concrete.

\section{REFERENCES}

[1] Young Min Joung, B.S., Dr. Zachary C. Grasley, "Evaluation and optimization of pervious concrete with respect to permeability and clogging".

[2] A.M. Amde and S. Rogge, "Specifications \& Development of high quality pervious concrete".

[3] Vimy Henderson and Robort Loy, "Behaviour and performance of pervious concrete pavement".

[4] Darshan S. Shah 1, JayeshkumarPitroda, J.J.Bhavsar, "Pervious concrete concept for rural road pavement"

[5] IS 456 (2000) Indian Standard for Plain and Reinforced Concrete - Code of Practice, Bureau of Indian Standards, New Delhi. 2002.

[6] IS 15388: 2003 Indian Standard for Silica Fume Specifications - Code of Practice, Bureau of Indian Standards, New Delhi. 2002.

[7] IS 10262: 2009 Indian Standard for Guidelines For Concrete Mix Design - Code of Practice, Bureau of Indian Standards, New Delhi. 2002. 


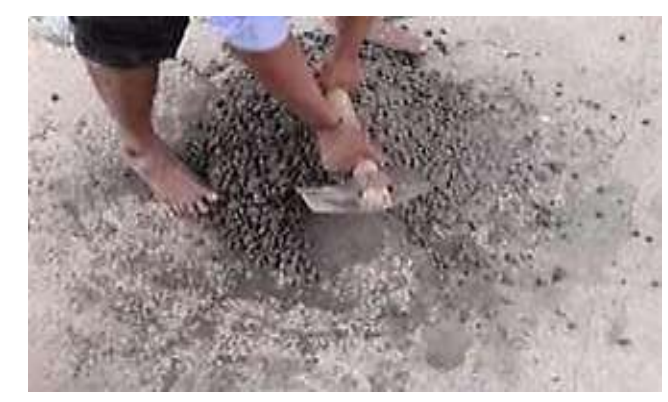

Figure 1. Mixing of ingredients

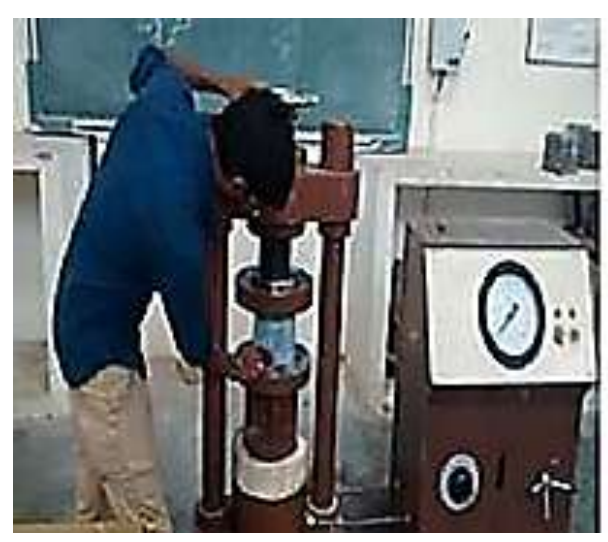

Figure 3.Compression Test of Cube Specimens

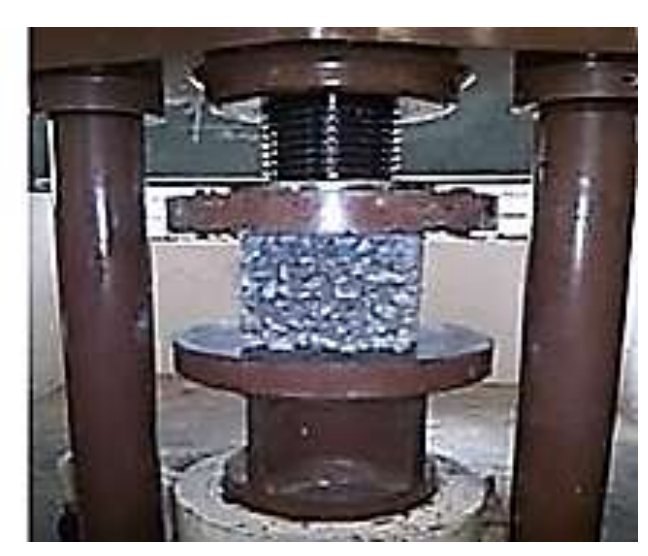

Figure 2. Casting of Specimens

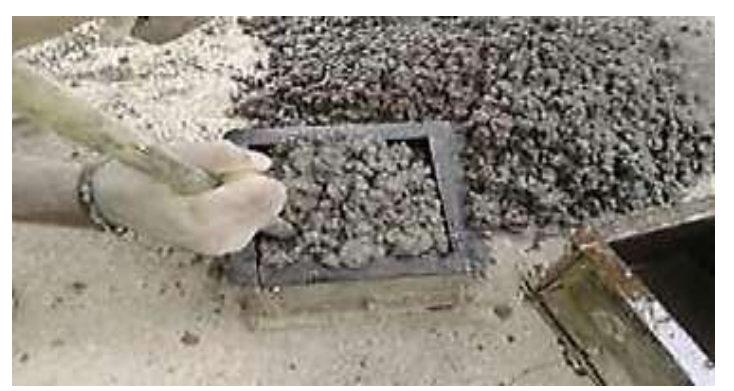

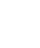

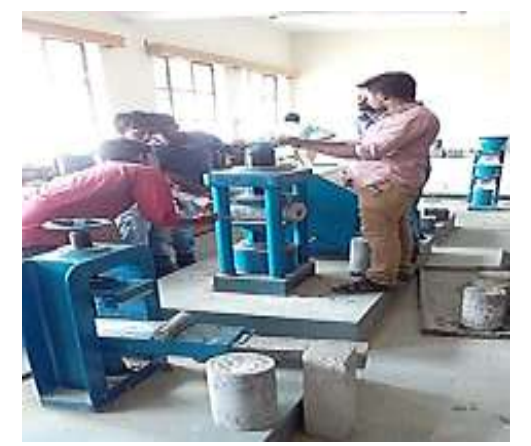

Figure 4.Split Tensile Test

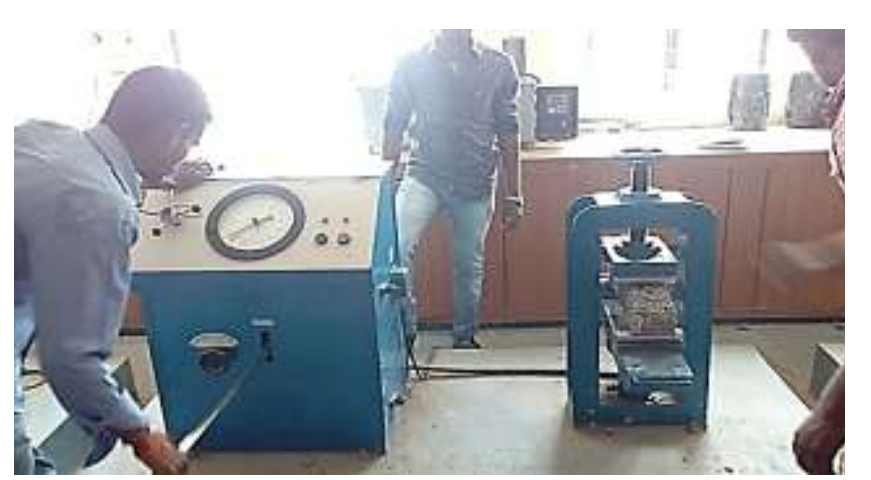

Figure. 5 Flexural Test on prism

Table 1.Mix proportion of No Fine Concrete

\begin{tabular}{|c|c|c|c|c|}
\hline Mix & Cement & $\begin{array}{c}\text { Fine } \\
\text { Aggregate }\end{array}$ & $\begin{array}{c}\text { Coarse } \\
\text { Aggregate }\end{array}$ & Water \\
\hline $\begin{array}{c}\text { Conventional } \\
\text { concrete }\end{array}$ & 1 & 1 & 2 & 0.45 \\
\hline M1 & 1 & - & 2 & 0.45 \\
\hline M2 & 1 & - & 3 & 0.45 \\
\hline M3 & 1 & - & 4 & 0.45 \\
\hline
\end{tabular}




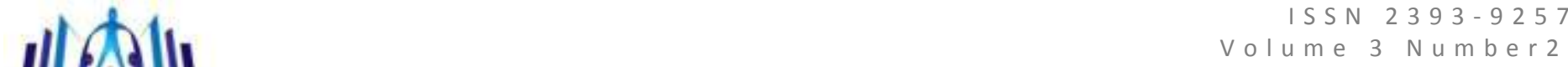

Table 2.Compressive Strength Results of Cube Specimens

\begin{tabular}{|c|c|c|c|c|c|}
\hline Mix & Day & Trial $-1,(\mathrm{kN})$ & Trial -2, (kN) & $\begin{array}{c}\text { Compressive } \\
\text { Strength, }\left(\mathbf{N} / \mathbf{m m}^{2}\right)\end{array}$ & $\begin{array}{c}\text { Percentage of its } 28^{\text {th }} \\
\text { day strength }\end{array}$ \\
\hline \multirow{3}{*}{ Conventional concrete } & $7^{\text {th }}$ & 401 & 410 & 18.0 & $48.65 \%$ \\
\hline & $14^{\text {th }}$ & 520 & 558 & 24.0 & $64.86 \%$ \\
\hline & $28^{\text {th }}$ & 860 & 820 & 37.0 & $100 \%$ \\
\hline \multirow{3}{*}{ M1 - 1:2 } & $7^{\text {th }}$ & 311 & 333 & 14.3 & $45.40 \%$ \\
\hline & $14^{\text {th }}$ & 548 & 559 & 24.6 & $78.10 \%$ \\
\hline & $28^{\text {th }}$ & 710 & 692 & 31.5 & $100 \%$ \\
\hline \multirow{3}{*}{ M2 - 1:3 } & $7^{\mathrm{th}}$ & 355 & 365 & 16.0 & $59.25 \%$ \\
\hline & $14^{\text {th }}$ & 455 & 480 & 21.0 & $77.78 \%$ \\
\hline & $28^{\text {th }}$ & 595 & 613 & 27.0 & $100 \%$ \\
\hline \multirow{3}{*}{ M3 - 1:4 } & $7^{\text {th }}$ & 192 & 203 & 8.7 & $62.14 \%$ \\
\hline & $14^{\text {th }}$ & 268 & 231 & 11.0 & $78.57 \%$ \\
\hline & $28^{\text {th }}$ & 320 & 305 & 14.0 & $100 \%$ \\
\hline
\end{tabular}

Table 3. Comparison of Compressive Strength of different Mix

\begin{tabular}{|c|c|c|}
\hline Mix & $\begin{array}{l}28^{\text {th }} \text { Day Compressive } \\
\text { Strength, }\left(\mathrm{N} / \mathrm{mm}^{2}\right)\end{array}$ & $\begin{array}{l}\text { Percentage with respect } \\
\text { to conventional concrete }\end{array}$ \\
\hline Conventional concrete & 37.0 & $100 \%$ \\
\hline M1 - 1:2 & 31.5 & $85.13 \%$ \\
\hline M2 - 1:3 & 27.0 & $72.97 \%$ \\
\hline M3 - 1:4 & 14.0 & $37.84 \%$ \\
\hline
\end{tabular}

Table 4. Split Tensile Strength of Cylinder Specimens at 28th Day

\begin{tabular}{|c|c|c|c|c|c|}
\hline Mix & Trial-1(kN) & Trial-2 (kN) & Trial-3(kN) & $\begin{array}{c}\text { Split Tensile } \\
\text { Strength (N/mm })\end{array}$ & $\begin{array}{c}\text { \% Difference with } \\
\text { Conventional Concrete }\end{array}$ \\
\hline $\begin{array}{c}\text { Conventional } \\
\text { concrete }\end{array}$ & 223 & 264 & 278 & 3.24 & $86 \%$ \\
\hline M1 - 1:2 & 170 & 209 & 214 & 2.79 & $64 \%$ \\
\hline M2 - 1:3 & 153 & 155 & 132 & 2.07 & $50 \%$ \\
\hline M3 - 1:4 & 114 & 121 & 108 & 1.613 & \\
\hline
\end{tabular}


Table 5.Flexural Test Values of No Fines Concrete at 28 Days Curing

\begin{tabular}{|c|c|c|c|c|}
\hline Mix & Trial-1, (kN) & $\begin{array}{c}\text { Trial-2, } \\
\mathbf{( k N )}\end{array}$ & $\begin{array}{c}\text { Flexural strength, } \\
\mathbf{( \mathbf { N } / \mathbf { m m } ^ { 2 } )}\end{array}$ & $\begin{array}{c}\text { \% Difference with } \\
\text { Conventional Concrete }\end{array}$ \\
\hline Conventional concrete & 11.9 & 12.5 & 4.88 & $77 \%$ \\
\hline M1 - 1:2 & 10.5 & 8.3 & 3.76 & $43 \%$ \\
\hline M2 - 1:3 & 5.38 & 5.2 & 2.1 & $28.7 \%$ \\
\hline M3 - 1:4 & 0.3 & 0.4 & 1.4 & - \\
\hline
\end{tabular}

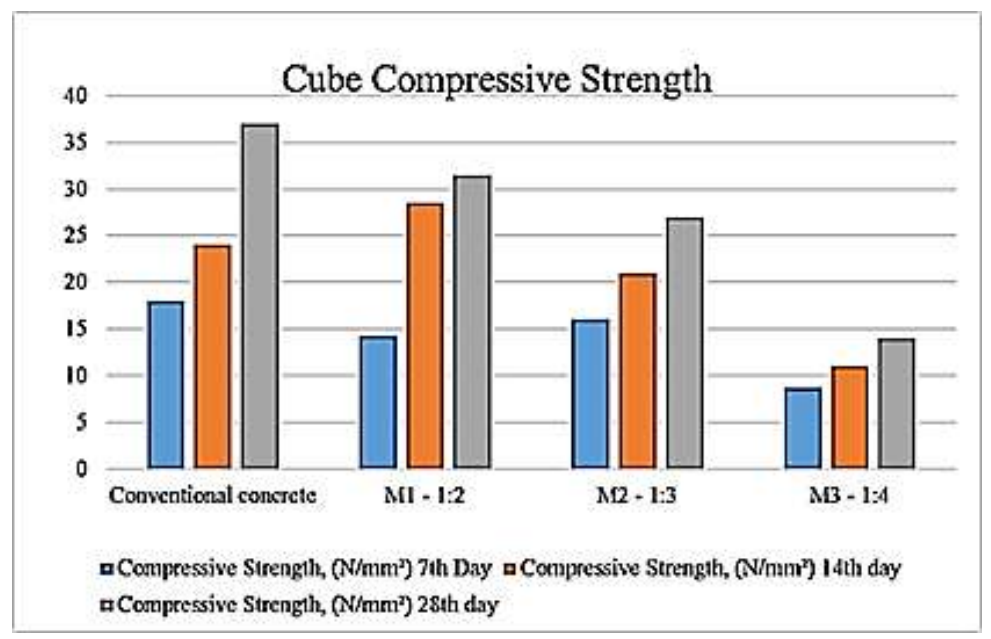

Figure. 6 Comparison of Conventional Concrete with No fine Concrete of Different Mix

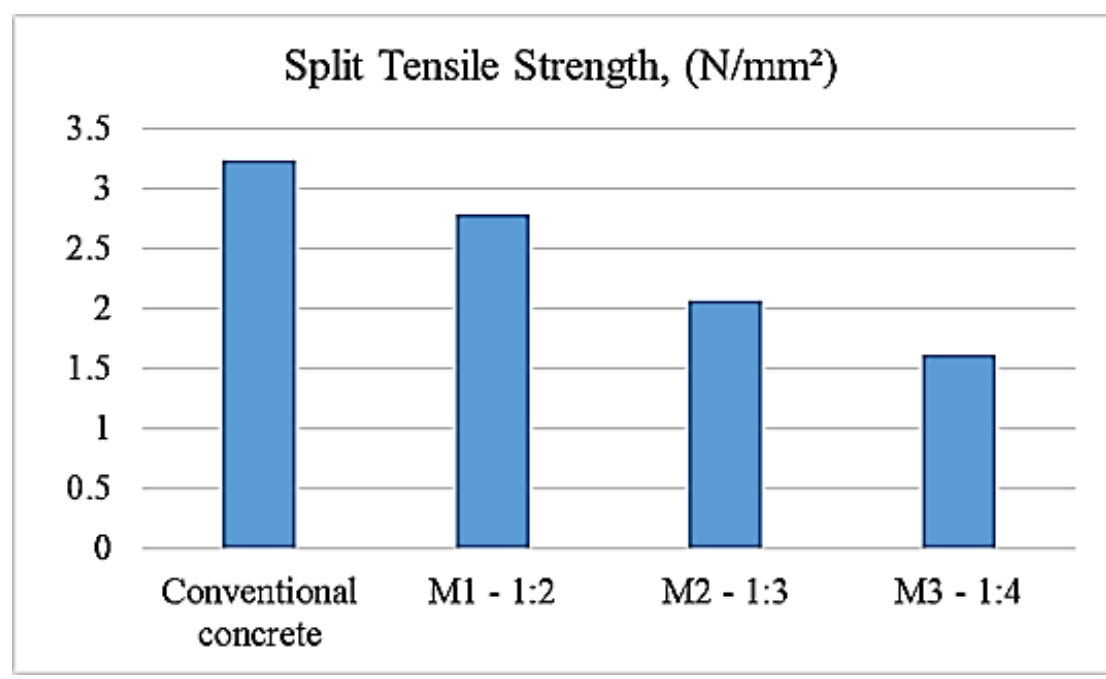

Figure. 7 Split Tensile Strength of Conventional Concrete with Different Mix Ratios of No Fine Concrete 


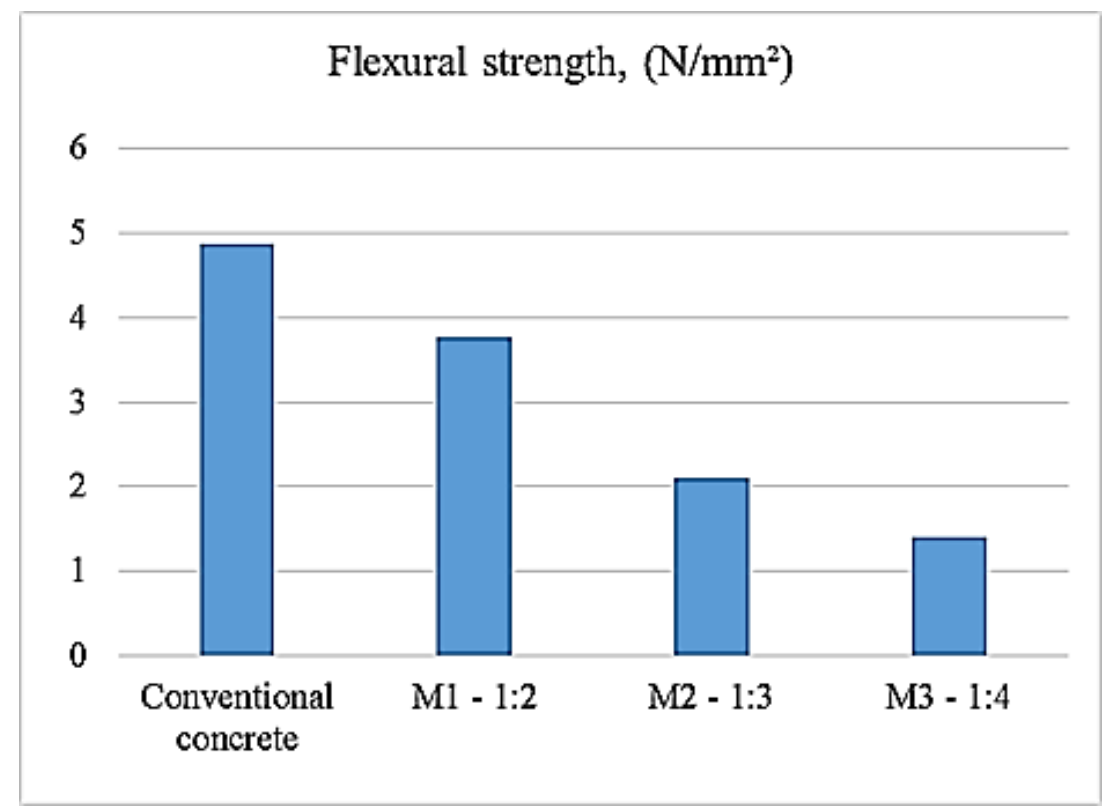

Figure. 8 Flexural strength of Conventional Concrete with No Fine Concrete of different mix ratios 